\title{
Successful Campus Outreach for Academic Libraries: Building Community through
} Collaboration. Edited by Peggy Keeran and Carrie Forbes. Lanham, MD: Rowman and Littlefield, 2018. 250 pp. Index. Softcover. \$50.00.

Outreach remains an elusive but essential facet of academic librarianship. Unlike relatively fixed imperatives such as cataloging or reference services, library outreach attempts to capture the shifting attention of a diverse mix of students, faculty, and community audiences. With demanding work schedules, ever-changing social media platforms and usage, as well as budget constraints, it is not difficult to imagine that a volume of case studies about thoughtful outreach projects that worked and the methods used to measure their success would feel like a life raft to archivists and librarians who often feel like they are just treading water in a vast sea of outreach. Librarians may have found such a source in Successful Campus Outreach for Academic Libraries: Building Community through Collaboration, which demonstrates a wide range of innovative outreach activities as well as provides methods for scalability and for measuring outcomes. Its value for archivists, however, is not quite so straightforward.

The editors, Peggy Keeran and Carrie Forbes, provide a detailed definition of "outreach" very early in the book:

Outreach is programming. Outreach is marketing and branding. Outreach is games, exhibits, and scavenger hunts. Outreach involves assessment and soliciting feedback from users. Outreach is about engaging with the local community beyond the university. Outreach is about connecting with marginalized communities who don't use the library or who may not feel welcome to use the library. Outreach is about promoting spaces, collections, and services. However, outreach is also fundamentally about connections, community, and collaboration (pp. vii-viii).

Given this understanding of outreach, that one finds evidence of connections, community, and collaboration within every case study represented in the book comes as no surprise. The types of "connections" presented in the case studies are K-12 outreach, serving digital natives, and student peer-mentoring, but also methods for establishing connections within the library itself, such as team building and professional development opportunities. The "community" these essays address are multifaceted layers of the community within the library walls, such as librarians and IT staff, as well as the students, faculty, and community they serve. Organized into four broad themes of "Strategic Vision and Planning," "From Start to Finish: Developing and Implementing Successful Programs," "Community Outreach: The Academic Library in the Community," and "Broadening Library Outreach Audiences," the book provides advice related to concepts that bridge the library and archives divide-most notably, project management, assessment, communication, exhibits, and student success.

While librarians and archivists spend a great deal of time trying to build audiences and make the case for their importance within a community, the "community" in the book's title seems to be just as much about building community within institutions as with an outside constituency. In Rochelle Smith's inspired chapter, "Reconceptualizing Outreach: Leveraging Librarians' Knowledge and Curiosity to Enhance Collaboration,” 
the author discusses embedded librarianship as a partnership with faculty to enhance "what libraries and librarians bring to the intellectual life of the campus" (p. 19). Smith posits the librarian as an intermediary in the classroom who, in essence, gives students permission to be curious. While the professor retains the position of intimidating expert, the librarian inhabits the role of the curious knowledge-seeker, which students can more easily model. Reflecting on expertise within the library, Smith also discusses an in-house colloquium series that provides CV-building opportunities for librarians to pursue academic interests while also creating enriching programming for the university community and the public. In this latter example, the librarian possesses skills of both the expert and the knowledge-seeker, while staying firmly rooted within the library. As Smith explains: "Colloquia provide a valuable means of reaching out and engaging with the university community about content, rather than exclusively foregrounding our utility as finders and housers of information" (p. 28).

Sabrina Wong's chapter, “Books Are Not Enough,” discusses outreach initiatives that address the needs of the nontraditional students at her Canadian polytechnic university, Southern Alberta Institute of Technology (SAIT). She notes that her literature review leans toward traditional community college and university research because little has been published on polytechnic libraries. One feels her excellent article on data-driven programming tied to the university's strategic plan will be noted in future literature reviews of the subject. Nontraditional students often find themselves left out of library outreach efforts because their age, education, or career path place them outside the more traditional demographic of 18- to 22-year-old students. As the student engagement librarian at SAIT, Wong organized a four-step approach to help her library focus on student engagement: identify gaps and gather evidence, set up a student engagement mind-set, map a cohesive engagement plan, and plan for assessment (p. 169). Cohesive and thorough, her method would be applicable to identifying and implementing outreach plans for any campus library or archives, whether they work with traditional or nontraditional students.

While some of the case studies lend themselves to application in archives, most of them would require a great deal of imagination to make the connections. Esther Gil's "Money Smarts: Collaborating for Financial Literacy” and Paul Mascareñas and Janet Lee's "Information Literacy Outreach to Help Students Succeed in High School and College" are firmly rooted in librarianship and hold little value for archivists other than guidance on general planning and project management skills. Not surprisingly, the case study pertaining to exhibits contains effective strategies in an area where much crossover exists between librarians and archivists. Long Island University librarian Manju PrasadRao's essay, "Academic Library Exhibits and Programs: Outreach through Campus and Community Partnerships," describes the library's extensive exhibition program that reflects the diversity of the student body and community, as well as enhances the educational experience at a largely suburban campus in the shadow of the cosmopolitan New York City metro area. Using the library's successful approach to home-grown exhibits as well as enhancing ALA-sponsored traveling exhibits, Prasad-Rao outlines the objectives, methods, and outcomes used to engage students, faculty, and local community members. Of particular interest is the library's own exhibit titled Nonviolence: The Global 
Choice!, which included original student artwork, community lectures by LIU faculty, and other events, all of which were free and open to the public. The exhibit united areas within and outside of the library, particularly faculty, artists, public relations, and members of the community, and experienced success "beyond expectations" (p. 130). The program's success led to the library spinning off traveling exhibits displayed at numerous venues, including the United Nations headquarters in New York, 10 local libraries, and even schools in Nigeria. A website further enhanced its global reach, which Prasad-Rao effectively ties back to the core mission of the university and its motto "Urbi et Orbi," or "To the City and to the World" (p. 131). The success of the local and traveling exhibits was due to the curators' commitment to reinforcing the goals of their larger institution and reflecting the community they serve. Of course, one cannot expect that every archives or library exhibit will garner the same recognition as this example, but it is inspiring to read about Prasad-Rao's methods for engaging multilevel audiences through academic library exhibits.

While Successful Campus Outreach for Academic Libraries bridges many concepts tied to both libraries and archives, this is very much a librarian's book and will likely be of little utility to archivists. If there is any doubt, one must only look at the index to be sure. Despite being discussed, most notably in Rochelle Smith's chapter on embedded librarianship, archival terms such as "archives," "archivists," "oral history," or "special collections" are completely absent from the otherwise quite thorough index. While not being particularly helpful to academic archivists looking to up their outreach game, this book best serves as a clarion call to our profession to write our own volume dedicated to outreach in academic archives.

Carol Street

Undergraduate Research Archivist University of Kentucky Libraries 